\title{
References:
}

1. Lidiia Eberle, Alona Kobernik Pharmacological study of ointment based on Zingiber officinale extract. European vector of development of the modern scientific researches: collective monograph. 2nd ed. Riga, Latvia : «Baltija Publishing», 2021. - 420 p. ISBN: 978-9934-26-077-3 DOI: https://doi.org/10.30525/978-9934-26-077-3.

2. Lamazian H.R. Vyznachennia antyoksydantnoi aktyvnosti zabarvlenykh roslynnykh ekstraktiv in vitro / H.R. Lamazian, I.M. Sytnyk, P.A. Chernovol ta in. // Farmatsevtychnyi chasopys. 2015. №4. S. 60-64.

3. Eberle L., Kobernik A., Alexandrova O., Kravchenko I. Optimization of extraction methods for total polyphenolic compounds obtained from rhizomes of Zingiber officinale. Trends in Phytochemical Research. 2018. № 2(1). P. 37-42.

DOI https://doi.org/10.30525/978-9934-26-113-8-31

\section{РОЗТОРОПША ПЛАМИСТА ЯК ПОТЕНЦЙННЙ ЕНТЕРОСОРБЕНТ ТОКСИЧНИХ МЕТАЛІВ}

\author{
Калитовська М. Б. \\ кандидат фармачевтичних наук, \\ дочент кафедри фармачії та біології \\ Львівський наиіональний університет ветеринарної медицини \\ та біотехнології імені С. 3. Гжицького \\ Застрижна М. Л. \\ асистент кафедри фармаиії та біології \\ Львівський національний університет ветеринарної медицини \\ та біотехнології імені С. 3. Гжицького \\ Семійон-Луцишин О. В. \\ асистент кафедри фармакологіi \\ Львівський національний медичний університет \\ імені Данила Галицького \\ м. Львів, Україна
}

Вступ. Розторопша плямиста $є$ однорічною або дворічною рослиною, що належать до сімейства айстрових (складноцвітих). В плодах чи насінні розторопші плямистої містяться флаволигнани, силідіанін, 110 
силібін, силікристин, жирне масло, ефірна олія, смоли, біогенні аміни, фактор Т (відповідає за кількість тромбоцитів у крові людини), вітамін К, флавоноїди (у більшості кверцитин).

В шроті розторопші плямистої міститься силімарин, який являє собою комплекс біологічно активних речовин. Дана сировина містить флавонолігнали, слиз, дубильні речовини, мікроелементи і масла. До сімдесяти відсотків складу припадає на речовину силібінін [1].

Плоди розторопші містять: жирні (до 32\%) й ефірні (0,08\%) олії, смоли, слизи (до 5\%, в гідролізаті - рамноза, ксилоза, арабіноза, глюкоза, галактуронова кислота, бетаїн), біогенні аміни (тирамін, гістамін), флавоноїди (2,8-3,8 \%: силібінін, силідіанин, таксифолін, силікристин), а також у незначній кількості - кверцетин, силандрин, коніфериловий спирт і недавно виділений 2,3-дегідросилібин.

Головною лікарською сировиною е сам зрілий плід рослини. Однак значними лікувальними властивостями володіє корінь і сік 3 трави. У насінні міститься більше двохсот компонентів, які чинять оздоровчий потужний ефект на людський організм. 3 них можна виділити:

- Макроелементи.

- Мікроелементи.

- Силімарин.

У них накопичуються наступні макроелементи (мг/г): калій 9,2, кальцій - 1,66, магній - 4,2, залізо - 0,08, а також мікроелементи (мкг/г): марганець -0,1, мідь - 1,16, цинк - 0,71, хром - 0,15, селен - 22,9, йод $-0,009$, бор $-22,4$.

Крім того, в їх склад входить до 27\% білка, який містить 18 амінокислот. Серед них такі важливі, як треонін, лізин, гістидин, аргінін, валін, метіонін, ізолейцин, лейцин, фенілаланін, триптофан. За кількісним вмістом превалюють аргінін, валін, лейцин, лізин і фенілаланін. Із замінних амінокислот максимальна кількість припадає на глутамінову кислоту. Крім цього, вони багаті клітковиною $(26 \%)$, водорозчинними $\left(\mathrm{B}_{1}, \mathrm{~B}_{2}, \mathrm{~B}_{3}, \mathrm{~B}_{4}, \mathrm{~B}_{5}, \mathrm{~B}_{6}, \mathrm{~B}_{12}\right)$, необхідними для регуляції жирового обміну, живлення серцевого м'яза, нервової системи, шкіри, органів зору i жиророзчинними (A, D, E) вітамінами [2].

Розторопша плямиста відома своїми властовостями покращувати травлення та відновлювати функції печінки. Крім того, вона має протизапальні, знеболюючі та антигістамінні властивості.

На сьогоднішній день в медицині України знайшли застосування такі препарати 3 плодів розторопші, як Силібор, Дарсил, Гепарсил. Їх закордонними аналогами є Легалон, Карсил, Гепабене та ряд інших препаратів. Ці препатпти застосовують при різних захворюваннях 
печінки (зокрема гепатит, цироз), селезінки, жовчнокам'яній хворобі, коліті, холециститі, цукровому діабеті, захворюваннях крові, відкладеннях солей, болю у суглобах, запаленнях слизової оболонки шлунка та товстої кишки, геморої, атеросклерозі. У дерматології при таких захворюваннях, як вітиліго, псоріаз, облисіння, вуграх також використовують препарати на основі розторопші. Олія насіння розторопші має протизапальну, епітелізувальну, ранозагоювальну та гепатопротекторну дію, сприяє загоєнню виразок шлунка, покращує імунітет організму [3, 4].

Завадяки такому багатому складу розторопша плямиста повинна зменшувати токсичтну дія важких металів на живий організм, зокрема солей кадмію.

Мета роботи: Вивчити сорбційну здатність розторопші плямистої відносно солей кадмію.

Матеріали та методи досліджень. У дослідженнях використовувався шрот розторопші плямистої, водний розчин солі кадмію. Вивчалася сорбція іонів кадмію із воних розчинів шротом розторопші плямистої. Наважка даного сорбенту становила 0,5 г. Вміст іонів кадмію в стандартному розчині становив 11,2 мкг досліджуваної солі в 1 мл розчину. Відбирали по 10 мл цьго розчину, в якому вміст кадмію становив 112 мкг.

Сорбцію проводили в статичних умовах, шляхом настоювання шроту розторопші в розчині солі кадмію, при струшуванні, протягом 10 хв. Залишок несорбованих іонів кадмію визначали за реакцією iз сульфарсазеном спектрофотометричним методом [5, 6]. Попередньо будували градуювальний графік, за яким знаходили концентрацію іонів металу в досліджуваних розчинах. За їх результатами розраховували відсоток сорбції іонів кадмію шротом розторопші плямистої.

Результати та їх обговорення. Було досліджено, що розторопша плямиста $є$ досить непоганим сорбентом щодо солей кадмію. Високий ступінь сорбції зберігається в широкому діапазоні $\mathrm{pH}$, зокрема в області від слабокислого до слаболужного середовища. Саме така кислотність спостерігається у стравоході, шлунку та кишківнику, що дасть змогу розторопші сорбувати даний токсичний метал, який потрапив туди разом із харчовими продуктами чи рідиною. Очевидно, зв'язування іонів металу відбувається за рахунок наявності у розторопші білкових компонентів, клітковини та вітамінів. При цьому максимальна сорбція становить 98,15 \% при рН 7,2 (рис. 1) [7]. 


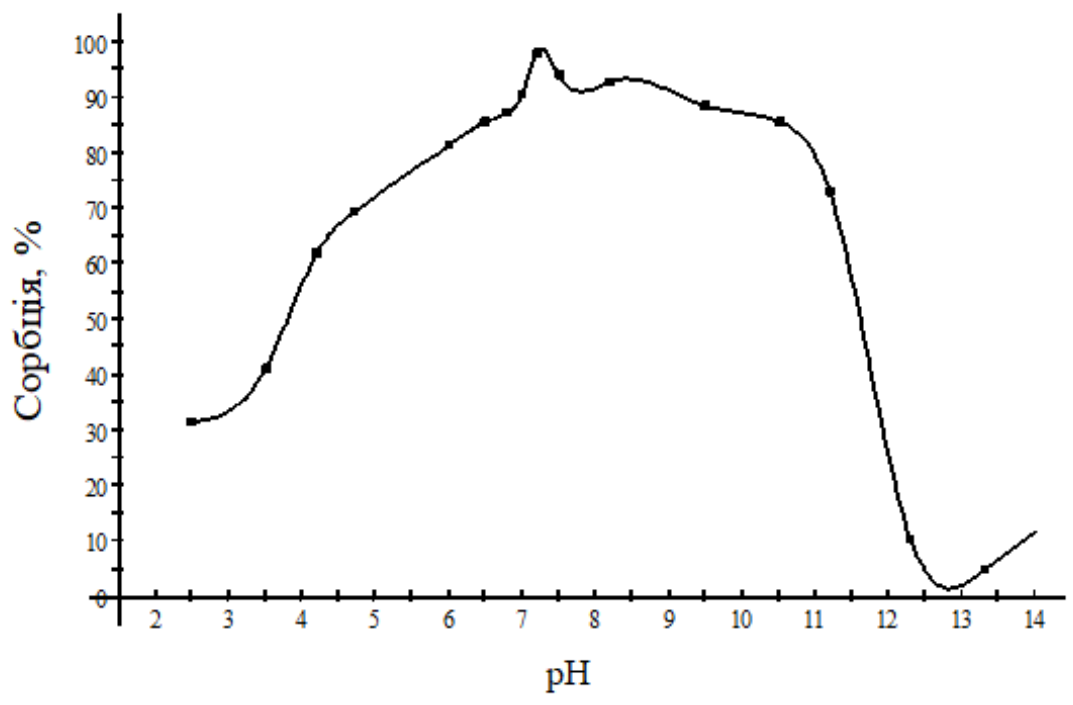

\section{Рис. 1. Залежність сорбції водного розчину кадмію шротом розторопші залежно від рН}

При збільшенні часу контакту розторопші із водним розчином кадмію від 10 до 60 хв сорбція зменшується приблизно на $16 \%$. Очевидно швидко наступає термодинамічна рівновага і розпочинається зворотній процес десорбції іонів кадмію із розторопші. Проте вилучення іонів металу залишається на досить високому рівні і становить 82,34 \%.

Отже, вилучення токсиканту із розчину з використанням розторопші плямистої відбувається досить швидко.

Висновок. Враховуючи результати проведених досліджень, розторопшу плямисту можна розглядати як потенційний ентеросорбент токсичних металів, зокрема солей кадмію. Дане питання потребує подальшого вивчення.

\section{Лiтература:}

1. Розторопша плямиста. http://factosvit.com.ua/roztoropsha-plyamysta/ (дата звернення: 19.06.2021).

2. Розторопша плямиста - «подарунок Діви Марії» http://agro-business.com.ua/agro/ekspertna-dumka/item/8201-roztoropshapliamysta-podarunok-divy-marii.html (дата звернення: 19.06.2021). 
3. Фармацевтична енциклопедія. Розторопша плямиста. https://www.pharmencyclopedia.com.ua/article/1140/roztoropsha-plyamista (дата звернення: 19.06.2021).

4. Розторопша. https://compendium.com.ua/dec/319729/ (дата звернення: 19.06.2021).

5. Калитовська М.Б. Валідація методики спектрофотометричного визначення кадмію у сечі. Аналітична хімія у фармації: матеріали II Міжнародної науково-практичної інтернет-конференції, 17 березня 2016 р. Харків, 2016. С. 14-15.

6. Чернова С.П. Л.В. Трубачева. Использование некоторых азореагентов при определении содержания ионов $\mathrm{Pb}(\mathrm{II}), \mathrm{Cd}$ (II) и $\mathrm{Hg}$ (II) Химия. 2006. № 8. С. 223-229.

7. Калитовська М.Б. Вивчення сорбційних властивостей розторопші плямистої відносно солей кадмію в залежності від $\mathrm{pH}$ розчину / М.Б. Калитовська // The $1^{\text {st }}$ International scientific and practical conference «Topical issues in pharmacy and medical sciences «, October 21-22, 2019. CPN Publishing Group. Tokyo, Japan. P. 179-183. 